\title{
Current characteristics of tuberculosis and human immunodeficiency virus co-infection in a cohort of hospitalized patients in Medellín, Colombia
}

\author{
Lina Ruiz*, María Angélica Maya1*, Zulma Vanessa Rueda², Lucelly López², Lázaro Agustín Vélez \\ 1 Grupo Investigador de Problemas en Enfermedades Infecciosas, Facultad de Medicina, Sede de Investigación \\ Universitaria, Universidad de Antioquia, Medellín, Colombia \\ 2 Facultad de Medicina, Universidad Pontificia Bolivariana, Medellín, Colombia \\ * Both authors contributed equally to this paper.
}

Introduction: Tuberculosis (TB) is an important cause of morbidity and mortality in HIV patients. It is unknown if the advent of molecular diagnostic methods and a greater availability of antiretroviral therapy (ART) in our country have changed some characteristics of the TB/HIV co-infection.

Objective: To describe the epidemiology, clinical features, diagnosis, resistance patterns, tuberculosis drug effects and mortality in co-infected patients.

Materials and methods: Retrospective study based on the review of medical records of hospitalized co-infected adults in a university hospital in Medellín, Colombia.

Results: A total of 178 patients was included in the study. TB and HIV diagnosis was simultaneous in $49.4 \%$. In the moment of TB diagnosis, the median CD4 count was 61 cells $/ \mu \mathrm{L}(27-145)$. Pulmonary tuberculosis (PTB) occurred in $28 \%$ of patients, extrapulmonary (EPTB) in $23 \%$, and mixed TB in $48.9 \%$. The main EPTB affectations were lymphatic (55.4\%), gastrointestinal (35.9\%), and of the central nervous system (18.7\%). Ziehl-Neelsen stain was positive in 137 patients (77\%), mycobacterium culture in 121 $(68 \%)$, and TB-PCR, in 85 of those patients in whom the test was done. Rifampicin resistance was detected in six cases (4.9\%). Transaminases (ALT) increased in half of the patients during TB treatment, but only $10 \%$ met liver-toxicity criteria. In-hospital mortality was $11.3 \%$. The single risk factor associated with mortality was CD4 count $<50 / \mu \mathrm{L}(\mathrm{RR}=3.9 ; 95 \% \mathrm{Cl}: 1.36-11.37 ; \mathrm{p}=0.01)$.

Conclusions: When it occurs as an opportunistic infection, TB usually leads to the diagnosis of advanced HIV disease. If used appropriately, TB diagnosis in these patients can be done by conventional methods. It is always necessary to monitor liver function during TB treatment and to rule out drug resistance.

Key words: Tuberculosis; HIV; acquired immunodeficiency syndrome; drug-related side effects and adverse reactions; drug resistance; molecular diagnostic techniques.

doi: https://doi.org/10.7705/biomedica.v38i3.3862

\section{Características actuales de la coinfección con tuberculosis y el virus de la inmunodeficiencia humana en pacientes hospitalizados en Medellín, Colombia}

Introducción. La tuberculosis es una causa importante de morbilidad y mortalidad en pacientes positivos para el HIV. Los métodos de diagnóstico molecular y una mayor disponibilidad del tratamiento antirretroviral en el país pueden haber cambiado las características de la infección concomitante.

Objetivo. Describir la epidemiología, las características clínicas, el diagnóstico, los patrones de resistencia, los efectos secundarios de los medicamentos antituberculosos y la mortalidad, en pacientes con las dos infecciones.

Materiales y métodos. Se hizo un estudio retrospectivo basado en la revisión de historias clínicas de adultos hospitalizados en un hospital universitario de Medellín, Colombia.

Resultados. Se incluyeron 178 pacientes en el estudio. El diagnóstico de tuberculosis e infección por el HIV fue simultáneo en 49,9\%. En el momento del diagnóstico, la mediana de CD4 fue de 61 células/ $\mu \mathrm{L}$ (rango de 27 a 145). La tuberculosis pulmonar ocurrió en $28 \%$ de los pacientes, la extrapulmonar en $23 \%$ y la mixta en $48,9 \%$. En la tuberculosis extrapulmonar, el compromiso fue principalmente linfático (55,4\%), gastrointestinal $(35,9 \%)$ y del sistema nervioso central (18,7 \%). La tinción de ZiehlNeelsen fue positiva en 137 pacientes (77\%), en tanto que el cultivo para micobacterias lo fue en 121 (68 \%). La reacción en cadena de la polimerasa para detectar la tuberculosis fue positiva en 85

\footnotetext{
Author's contributions:

Lina Ruiz and María Angélica Maya: data acquisition

Zulma Vanessa Rueda and Lucelly López: data analysis

All authors participated in the conception, design, data interpretation, review, drafting, and final approval of the manuscript.
} 
de los pacientes a quienes se les hizo la prueba. Se detectó resistencia a la rifampicina en seis casos $(4,9 \%)$. Al iniciar el tratamiento antituberculoso, las transaminasas se elevaron en la mitad de los pacientes, pero solo $10 \%$ cumplieron los criterios de hepatotoxicidad. La mortalidad hospitalaria fue de $11,3 \%$. El único factor de riesgo asociado con la mortalidad fue un conteo de CD4 menor de 50/ $\mu \mathrm{L}\left(\mathrm{RR}=3,9 ; \mathrm{IC}_{95 \%} 1,36-11,37 ; \mathrm{p}=0,01\right)$.

Conclusiones. Cuando la tuberculosis se presenta de manera oportunista, comúnmente lleva al diagnóstico de enfermedad avanzada por el HIV. Su diagnóstico en estos pacientes puede hacerse con los métodos convencionales. Es necesario vigilar la función hepática durante el tratamiento y excluir la resistencia a los medicamentos.

Palabras clave: tuberculosis; VIH; síndrome de inmunodeficiencia adquirida; efectos colaterales y reacciones adversas relacionados con medicamentos; resistencia a medicamentos; técnicas de diagnóstico molecular.

doi: https://doi.org/10.7705/biomedica.v38i3.3862

Tuberculosis (TB) continues to be an important cause of morbidity and mortality in individuals that are positive for the human immunodeficiency virus (HIV). Worldwide, $11.2 \%$ of the 10.4 million new TB cases in 2015 occurred in HIV-infected individuals. HIV co-infection is an important risk factor for the acquisition and development of active TB (1). Tuberculosis was reported to cause 1.4 million of deaths in 2015, 0.4 million of them among HIVpositive patients. In 2015, 268,000 active TB cases were reported in the Americas, $12 \%$ were coinfections with HIV, and $19 \%$ of patients died due to the co-infection. In that same year, 15,000 active TB cases were reported in Colombia, of which 14\% were co-infections with HIV, similar to the $16 \%$ reported in 1995 in our institution (Velásquez G, García H, Arboleda C, Castro J, Díaz S, Garcés MC, et al. Características de la enfermedad tuberculosa y cumplimiento con las normas de aislamiento en un hospital universitario entre 1995 y 1998. Resumen A3. II Encuentro Nacional de Investigación en Enfermedades Infecciosas. Infectio. 2000;4:17).

Many co-infected patients are diagnosed only when they reach a third-level center; therefore, the diagnosis is late and leads to prolonged hospitalizations. Exploring risk factors for late diagnosis in 191 co-infected patients, Rossato, et al. (2) found that extrapulmonary TB and smear-negative TB contributed significantly to this delay.

HIV coinfection increases the risk of tuberculosis drug-induced liver injury (DILI) (3), complicating

Corresponding author:

Lázaro Agustín Vélez, Grupo Investigador de Problemas en Enfermedades Infecciosas, Facultad de Medicina, Sede de Investigación Universitaria, Universidad de Antioquia, Calle $62 \mathrm{~N}^{\circ}$ 52-59, torre 1, laboratorio 630, Medellín, Colombia Telephone: (574) 2196541

clamona@une.net.co

Received: 03/04/17; accepted: 28/02/18 management and frequently forcing the discontinuation of first-line therapy and the use of alternative medications. On the other hand, TB/HIV co-infection also increases the risk of drug-resistant tuberculosis (4). These diagnostic and management challenges, adverse effects, and drug interactions all contribute to increase hospitalization rates and duration, as well as the cost of the therapy, with associated worse outcomes.

Recently, the advent of new molecular diagnostic tests for TB and a greater availability of antiretroviral therapy (ART) in Colombia may have changed the characteristics of TB/HIV co-infection in our patients. This study aimed to evaluate the current features of the co-infection, tuberculosis drug effects starting therapy, the impact of TB resistance and mortality in a cohort of TB/HIV co-infected patients hospitalized in a high-complexity hospital in Medellín, Colombia.

\section{Materials and methods \\ Study design and population}

We conducted a retrospective clinical chart review of hospitalized patients with TB/HIV co-infection in the Hospital Universitario San Vicente Fundación, (HUSVF) (a reference healthcare center for these kind of patients) in Medellín, Colombia, between 2007 and 2015, and of registers from Antioquia's health information systems (Dirección Seccional de Salud de Antioquia, DSSA).

Inclusion criteria were age 15 years or older with a confirmed diagnosis of HIV and active TB infection, and complete access to the medical record of everyone. Patients were excluded in the absence of confirmed HIV or TB infection when charts were not available, or when any other mycobacteria different from Mycobacterium tuberculosis grew in the culture. All patients were under the medical care of the infectious diseases section of the Hospital. 


\section{Data collection and definitions}

We collected all the demographic and epidemiological variables, as well as clinical, laboratory and treatment information regarding the co-infection. The confirmation of HIV infection required a positive Western blot or HIV viral load. In patients with a compatible clinical picture and no alternative diagnosis to explain it, TB was defined by the positivity of at least one of the following: i) ZiehlNeelsen (ZN) stained smear; ii) $M$. tuberculosis culture; iii) ZN positive in compatible histopathology, and iv) $M$. tuberculosis molecular tests according to the diagnostic criteria of the World Health Organization (5). We used Ziehl-Neelsen stain for the entire duration of the study. Regarding the media for mycobacterial cultures, Ogawa was used between 2007 and 2012, Lowenstein from 2012 to 2015 and MGIT liquid culture as of 2015. Molecular tests have been performed since 2011 in the Hospital. Lymphocytes CD4+ count, HIV viral load, hepatitis $B$ and $C$, and syphilis serology were obtained during the same hospitalization period in which co-infection was diagnosed.

Anemia was defined as a hemoglobin level of less than $13 \mathrm{~g} / \mathrm{dl}$ in men and less than $12 \mathrm{~g} / \mathrm{dl}$ in women; leukopenia as cell counts less than 4,000/ $\mu \mathrm{L}$, and thrombocytopenia as platelet count less than $100,000 / \mu \mathrm{L}$. Clinical instability at admission was defined as a patient with at least three of the following vital signs out of normal range: Heart rate, $60-100 /$ minute; spontaneous respiratory rate, 12-22/minute; systolic blood pressure, $90-120 \mathrm{~mm}$ $\mathrm{Hg}$; temperature, $36.5-38.2^{\circ} \mathrm{C}$, and pulse oximetry $\geq 90 \%$ without supplementary oxygen.

The TB clinical presentation was classified as pulmonary, extrapulmonary or mixed according to the compromised organs. TB treatment was categorized in two groups: i) First-line scheme [isoniazid $(H)$, rifampicin $(R)$, pyrazinamide $(Z)$ and ethambutol (E)], and ii) a modified scheme when due to the clinical condition, adverse events, comorbidities, drug interactions or resistance to any TB medication, treatment included medications different from the first-line scheme.

Hepatotoxicity was defined as serum values of alanine aminotransferase (ALT) five times above the upper limit of normal (ULN) values in asymptomatic patients, or more than three times in patients with jaundice or gastrointestinal symptoms (6). Due to the retrospective character of the study, other clinical complications and adverse events associated with TB medications were only considered if they were verified by the specialist in infectious diseases in charge and documented in the clinical chart.

Poor adherence to treatment was defined as partial or total interruptions of treatment for more than a week prior to hospitalization, either by the patient's own decision or due to difficulties in accessing health services. Due to the nature of the chart review, we were not able to differentiate between them.

Positive cultures for mycobacteria were sent to Antioquia's laboratory of public health (Laboratorio de Salud Pública) for first-line drugs susceptibility testing. There, the susceptibility to rifampicin was confirmed by molecular methods and to all the first-line drugs by the proportions method. If MDR was found, these resistant strains were sent to the laboratory of the Instituto Nacional de Salud for evaluating the susceptibility to second-line drugs.

\section{Statistical analysis}

After we screened the database of all HIV patients for co-infection with TB, we did descriptive statistics of collected data. All variables were expressed as percentage or median and interquartile range (IQR). We evaluated risk factors associated with mortality using a binomial regression analysis adjusted by age. Covariates included in the analysis were previous ART, homelessness, previous TB, hepatitis $B$ infection, main organs affected by $T B$, CD4 count cells $<50 / \mathrm{mm}^{3}$, HIV viral load $\geq 100,000$, reactive VDRL, and hepatotoxicity. Results were expressed as adjusted relative risk with their 95\% confidence interval. Data were analyzed in the statistic program SPSS ${ }^{\mathrm{TM}}$, version 22, and Stata ${ }^{\mathrm{TM}}$, version 12.0.

\section{Ethics statement}

The ethical committees of the Universidad de Antioquia and the HUSVF approved the study.

\section{Results}

We screened 221 hospitalized patients with suspected TB/HIV co-infection within the 2007-2015 period of whom 178 were included and 43 excluded. The main baseline features of these patients are shown in table 1.

TB and HIV diagnosis were confirmed simultaneously in $49.4 \%$ patients $(86 / 174)$; of the remaining individuals with previous HIV diagnosis, only 38 had been on ART, the majority of them with poor adherence and advanced immunosuppression. 
Table 1. Baseline characteristics of 178 hospitalized patients with TB/HIV co-infection in a university hospital in Medellín, Colombia

\begin{tabular}{ll}
\hline General characteristics & \\
\hline Age, years, median (IQR) & $38(29-45)$ \\
Male sex, $\mathrm{n}(\%)$ & $137 / 178(77)$ \\
HIV status & \\
$\quad$ Known HIV diagnosis at admission, $\mathrm{n}(\%)$ & $88 / 174(50,6)$ \\
HIV viral load (copies/ $\mu$ l), & 191,000 \\
median (IQR) & $(42,300-750,000)$ \\
Lymphocytes T CD4+ count & $61(27-145)$ \\
(cells/mL), median (IQR) & $28 / 176(16)$ \\
CD4 $>200$ cells/mL, $\mathrm{n}(\%)$ & $74 / 176(42)$ \\
CD4 50-200 cells/mL, $\mathrm{n}(\%)$ & $74 / 176(42)$ \\
CD4 <50 cells/mL, $\mathrm{n}(\%)$ & \\
Past medical history, $\mathrm{n}(\%)$ & $37 / 176(21)$ \\
Previous TB episode & $47 / 141(33.3)$ \\
Previous exposition to hepatitis B virus & $4 / 152(2.6)$ \\
Previous exposition to hepatitis C virus & $6 / 178(3.4)$ \\
Alcoholism & $5 / 178(2.8)$ \\
Chronic kidney disease & \\
Epidemiological conditions, $\mathrm{n}(\%)$ & $26 / 177(14.7)$ \\
Homeless & $13 / 123(10.6)$ \\
Previous contact with a TB patient & $6 / 176(3.4)$ \\
Prisoners & $4 / 175(2.3)$ \\
Intravenous drugs users &
\end{tabular}

Other co-infections diagnosed during hospitalization were toxoplasmosis in $10 \%$ of patients, histoplasmosis in $5.6 \%$, cryptococcosis in $4.5 \%$, and pneumocystosis in $3.4 \%$. More than half $(56.6 \%)$ of the patients had prior history of syphilis, $33 \%$ had been naturally exposed to wild hepatitis $B$ virus (reactive $A b H B c \lg G$ ), $8.9 \%$ were chronic carriers of Ags HB, and $19 \%$ had developed protective titers of AbHBs (>10 mlU/mL); $2.6 \%$ had evidence of previous exposition to hepatitis C (positive anti-HCV) (table 1).

At admission, $15 \%$ of patients had evidence of clinical instability, $86 \%$ anemia, 20\% leucopenia, $23.5 \%$ thrombocytopenia, and 111 of 177 (63\%) had liver function tests within normal range.

\section{Clinical characteristics of TB in HIV-positive patients}

Table 2 shows the clinical features at admission. Around $28 \%$ (50) of patients had pulmonary TB (PTB), 23\% (41) extrapulmonary TB (EPTB) and $49 \%$ (87) disseminated disease. The organs and systems commonly affected in EPTB were lymphatic nodes $(55.4 \%)$, peritoneum or gastrointestinal tract $(35.9 \%)$, central nervous system $(18.7 \%)$, and pleura $(9.3 \%)$. Other TB presentations were genito-urinary (6 cases), bone marrow (6 cases), osteoarticular (3 cases), muscular (3 cases), pericardial (2 cases), laryngotracheal (1 case), ophthalmic ( 1 case), dorso-lumbar myelitis (1 case), mastoiditis (1 case), and cutaneous ( 1 case).

\section{Microbiological diagnosis of TB}

Table 3 shows the laboratory tool used for the diagnosis of TB. In general, Ziehl-Neelsen (ZN) stain was positive in 137 patients $(77 \%)$, culture in $121(68 \%)$, and $M$. tuberculosis PCR in 85 of the patients in whom this test was done. However, PCR supported the TB diagnosis in 25 patients with negative ZN. In 29 (16.3\%) of the 178 patients the diagnosis was made only with $\mathrm{ZN}$, and three of them died during the follow-up. In the two cases with negative $Z N$, culture and PCR, TB diagnosis was based on histopathology with positive $\mathrm{ZN}$ in tissues, clinical picture compatible with TB, and absence of an alternative diagnosis.

\section{Drug-susceptibility testing}

Among all first-line antibiotics tested, resistance to rifampicin was detected in six of 123 cases with available information (4.9\%): Four had multidrugresistant tuberculosis (MDR-TB), one had preextensively drug resistance (pre-XDR), resistance to INH, SM, RMP, and EMB (HRSE), ethionamide and levofloxacin, and no susceptibility test to pyrazinamide available (this patient had prior history of treated gastrointestinal TB and drug

Table 2. Clinical characteristics of TB in 178 HIV-positive patients

\begin{tabular}{lr}
\hline Characteristics & $\mathbf{n}(\%)$ \\
\hline Symptoms & \\
Fever & $154 / 178(86.5)$ \\
Cough & $136 / 178(76.4)$ \\
Weight loss & $132 / 178(74.2)$ \\
Diarrhea & $99 / 178(55.6)$ \\
Night sweats & $87 / 178(48.9)$ \\
Dyspnea & $63 / 178(35.4)$ \\
Headache & $62 / 178(34.8)$ \\
Stomachache & $57 / 178(32)$ \\
Altered mental status & $26 / 177(14.7)$ \\
Chest pain & $23 / 178(12.9)$ \\
Signs & \\
Lymphadenopathy & $105 / 177(59.3)$ \\
Hepatomegaly & $43 / 178(24.2)$ \\
Splenomegaly & $26 / 178(14.6)$ \\
Ascites & $6 / 178(3.4)$ \\
Abdominal mass & $4 / 177(2.3)$ \\
TB presentation & \\
Pulmonary, exclusively & $50 / 178(28.1)$ \\
Extrapulmonary, exclusively & $41 / 178(23.0)$ \\
Mixed presentation & $87 / 178(48.9)$ \\
Radiographic patterns & \\
Hilar or paratracheal lymphadenopathies & $68 / 173(39.3)$ \\
Miliary pattern & $40 / 172(23.3)$ \\
Cavitations & $20 / 173(11.6)$ \\
Other findings compatibles with TB* & $111 / 173(64.2)$ \\
\hline Anyonewth to & \\
\hline
\end{tabular}

*Anyone with the following radiological findings: Pleural effusion, budding tree pattern, consolidation, or interstitial opacities 
Table 3. Percentage of HIV/TB co-infected patients whose microbiological TB diagnosis was obtained by one or more diagnostic methods

\begin{tabular}{lcr}
\hline Microbiological method & $\mathbf{n}$ & $\%$ \\
\hline ZN+, culture+, PCR+ & 45 & 25,3 \\
ZN+, culture+, PCR- & 48 & 27,0 \\
ZN+, culture-, PCR+ & 15 & 8,4 \\
ZN+, culture-, PCR- & 29 & 16,3 \\
ZN-, culture+, PCR- & 14 & 7,9 \\
ZN-, culture-, PCR+ & 11 & 6,2 \\
ZN-, culture+, PCR+ & 12 & 6,7 \\
Culture +, PCR+ $\left.{ }^{*}\right)$ & 2 & 1,1 \\
ZN-, culture-, PCR- $\left(^{* *}\right)$ & 2 & 1,1 \\
\hline
\end{tabular}

ZN: Ziehl-Neelsen stain; culture: Mycobacterium culture; PCR: Polymerase chain reaction

* No ZN available for two patients

${ }^{* *}$ In two of the patients, diagnosis was made by compatible histopathology with positive $\mathrm{ZN}$ in tissues

addiction disorder). The sixth case had resistance to rifampicin by a genotyping test (Gene Xpert ${ }^{\mathrm{TM}}$ MTB/RIF), but no susceptibility testing to other anti-tuberculous drugs was done.

\section{Adverse events associated with anti-TB drugs}

TB therapy was started in the hospital in 169 patients, 159 with the first-line scheme (HRZE), three with HZE plus moxifloxacin, one with RZE plus moxifloxacin, one with HRZ plus levofloxacin, two with HZE plus rifabutin, and three with secondline medications. Five did not receive in-hospital TB therapy because acid-fast stains had been negative and they were discharged before culture results were available, two died before the treatment could be initiated, and for two of the patients we had no available information.

An ALT increase was the most frequent adverse event associated with anti-TB therapy. ALT was measured in 177 patients and more than once in 152 (median=4.0, IQR: 2.0-6.0). Before starting TB treatment, the median of ALT was $26 \mathrm{U} / \mathrm{L}$ (IQR: 18-48). ALT was followed up for 18 days (IQR: 12$29)$ and 12 days was the time to get the maximal ALT value (IQR: 8-17). Among the 152 patients with more than one value available, 98 started TB treatment with normal ALT (64\%), and $76(50 \%)$ had an increase during the treatment; in eight the ULN increased between 3 and 5 times, in seven, more than 5 times, while none of the other 54 patients (36\%) who started with an ALT level higher than the ULN increased more than twice the basal value.

Of the 159 patients who started on HRZE, 134 (84\%) continued on the same medications at discharge, but $25(16 \%)$ were switched to a modified scheme.
Hepatotoxicity, according to the established definition, was present in 15 cases (10\%); three of them restarted the same medications once normal values were reached, and 12 begun a modified treatment. In addition to liver toxicity, in 13 patients there were other reasons to change TB treatment: Nine cases due to drug interactions, two cases because of in-hospital detection of drug-resistant TB, and one case because of bone marrow toxicity and another discontinuation attributed to arthralgias. Other reported side effects that did not require interruption or changes on anti-TB treatment were bone marrow toxicity in 6\%, skin allergy in $3 \%$, and neurotoxicity and nephrotoxicity in three and two cases, respectively. The immune reconstitution inflammatory syndrome (IRIS) was detected in 4\% of the patients.

\section{Risk factors associated with mortality}

The median hospital stay was 19 days (IQR: 1328 ), and the in-hospital mortality was $11.3 \%$ (20 of 177). According to registers of the local health information systems, at the end of February of 2015,61 of the patients included in this study had died $(34.3 \%)$. By multivariate analysis, having a CD4 count below 50 cells $/ \mathrm{mL}$ was the only risk factor associated with in-hospital mortality ( $R R=3.94,95 \% \mathrm{Cl} 1.36-11.37$ ) (table 4).

\section{Discussion}

Our results highlight the fact that $\mathrm{TB}$, a common opportunistic infection, led to the diagnosis of advanced HIV disease in about half of co-infected patients included in the study. Most of them were very immunocompromised and presented with disseminated and extrapulmonary disease, and almost 5\% were resistant to rifampicin (generally associated with other resistances). During hospital stay, $16 \%$ had to interrupt or modify the TB first-line drugs ( $10 \%$ by hepatotoxicity), and CD 4 cells $<50 /$ $\mu \mathrm{L}$ at admission was the single factor associated with in-hospital mortality.

Despite of the knowledge amassed about HIV infection, the progress in ART and a better access of patients to it worldwide, as well as the availability of rapid diagnostic and drug-susceptibility tests for TB in the last years, our results show that even in countries with moderate TB incidence like Colombia, TB is still frequently diagnosed among patients with advanced HIV-associated immunosuppression (Velásquez G, Mejía P, Restrepo N, Betancour J. Comportamiento de la tuberculosis en paciente infectados por el virus de la inmunodeficiencia 
Table 4. Risk factors associated with in-hospital mortality among co-infected HIV-TB patients (bivariate and multivariate analysis)

\begin{tabular}{|c|c|c|c|c|}
\hline Variable & Crude RR $(95 \% \mathrm{Cl})$ & $p$ value & Adjusted RR (95\% Cl) & $p$ value \\
\hline Prior antiretroviral therapy & $0.80(0.33-1.90)$ & 0.61 & & \\
\hline Homeless & $1.02(0.32-3.23)$ & 0.98 & & \\
\hline Prior TB & $0.43(0.10-1.76)$ & 0.24 & $0.56(0.15-2.01)$ & 0.37 \\
\hline Hepatitis B infection & $0.82(0.21-3.13)$ & 0.78 & $0.86(0.22-3.38)$ & 0.82 \\
\hline Pulmonary TB & $1.66(0.51-5.36)$ & 0.40 & & \\
\hline Gastrointestinal TB & $2.03(0.86-4.81)$ & 0.11 & $1.54(0.70-3.38)$ & 0.28 \\
\hline Meningeal TB & $2.07(0.76-5.62)$ & 0.16 & & \\
\hline TB lymphadenitis & $0.28(0.08-0.91)$ & 0.03 & $0.40(0.12-1.36)$ & 0.14 \\
\hline CD4 count $<50 / \mathrm{mL}$ & $5.17(1.79-14.94)$ & 0.00 & $3.94(1.36-11.37)$ & 0.01 \\
\hline Viral load $\geq 100,000$ & $0.80(0.35-1.83)$ & 0.60 & & \\
\hline VDRL & $1.58(0.68-3.70)$ & 0.29 & & \\
\hline Hepatotoxicity & $1.01(0.36-2.83)$ & 0.99 & & \\
\hline
\end{tabular}

Model adjusted by age

humana. Resúmenes del Segundo Encuentro Nacional de Investigación en Enfermedades Infecciosas. Medellín, Sociedad Colombiana de Infectología, 2000:4(1) Abs. E3:32.) (7-14).

Some possible reasons include late access to health systems (our hospital serves a community with low resources and poor access to health services) and structural delays in access to diagnosis and care. Barriers for antiretroviral therapy initiation are present despite global access to free antiretrovirals, which partially explains the fact that only 38 of the previously diagnosed individuals were on ART. The lack of early access to ART, even in the face of opportunistic infection, leads to repeated admissions, high costs, and poor outcomes. Individual characteristics such as alcohol and drug addiction, poor awareness of risk behaviors, misinformation regarding HIV disease (both among doctors and patients), and the fear of HIV test contribute as well to this situation. The fact that more than half of our patients are young adults previously exposed to other sexually transmitted diseases as syphilis and hepatitis B suggests poor knowledge about preventive measures and no awareness about risk behaviors, as well as limited access to HIV testing, which is a very important issue in our city.

Methods to diagnose TB are imperfect, therefore, many studies have shown that the association of fever, cough and weight loss should prompt diagnostic investigations in search for TB among HIV infected patients $(15,16)$. In our study, confirmation of TB required the simultaneous use of multiple ZN stained smears and mycobacterial cultures, not only in pulmonary samples but also in many extrapulmonary specimens. In that sense, the study draws attention to the good diagnostic yield of the conventional methods such as ZN stain in all kind of samples $(70 \%$ in respiratory samples and $51 \%$ in other samples), which could be explained by the multiple studies conducted in all affected organs (17-19).

On the other hand, the systematic study of all bronchoalveolar lavage (BAL) samples with very well trained staff increases the diagnostic yield of pulmonary TB in HIV patients (17). Our findings are in keeping with previously published reports suggesting that traditional microbiologic tests are still effective to diagnose the TB/HIV co-infection (20-22), which highlights the importance of sample quality and their systematic study.

The rate of rifampicin resistance in our co-infected patients was more than three times the $1,5 \%$ observed in the general population (23), similar to the $5 \%$ estimated globally for MDRTB (24), but different to the $19 \%$ reported in Eastern Europe, $7 \%$ in the Western Pacific region (25), and up to $18-26 \%$ of newly diagnosed TB cases in some countries (26). According to these findings, testing for TB drugs susceptibility, especially with molecular methods for first- and second-line ones, are mandatory for the timely management of all co-infected patients.

Resistance to rifampicin is usually associated with resistance to isoniazid and other drugs. However, monoresistance to rifampicin has been described in HIV-co-infected patients when they have been treated with intermittent rifampicin therapy and their CD4+ count is less than 100 cells/ $\mu \mathrm{L}(27)$. It does not seem to be the problem in our patients, whose greatest risk of resistance is the poor adherence to the TB therapy (27-29); in fact, in the single patient whose resistance to rifampicin was confirmed only by Gene Xpert MTB, it was not possible to exclude resistance to other antibiotics. 
Even though $50 \%$ of our patients experienced increases in ALT values after beginning the firstline TB treatment, only $9.4 \%$ (15 out of 159 ) had to interrupt it because of liver toxicity; however, contrary to expectations, in our study high basal ALT values did not predict hepatotoxicity due to TB therapy and, therefore, it did not lead to changes in the treatment. This prevalence is similar to the rates reported in India by Saha, et al. (30), who identified co-infection with hepatitis B or hepatitis $C$ as risk factors for liver toxicity. We measured ALT values before starting TB treatment and could follow them closely until patients were discharged. In this study, neither co-infection with hepatitis B or $C$ were associated with hepatotoxicity due to TB drugs. As biomarkers to predict liver toxicity have not been developed yet, the findings highlight the importance of closely monitoring the ALT levels in all TB/HIV patients, and not only in those with chronic hepatic diseases.

As demonstrated in other studies, we found that CD4 counts below 50 cells $/ \mu \mathrm{L}$ were associated with in-hospital mortality (31). Again, this underpins the need to address the factors underlying late access to therapy. This subgroup of patients should be closely monitored, and considering their high mortality risk and the non-significant relevance of the immune reconstitution inflammatory syndrome (IRIS) in most of them (only described in $4 \%$ of our patients), it is imperative to initiate the ART as soon as possible, usually two weeks after starting the TB treatment $(32,33)$.

The main limitations of our study are related to its retrospective nature, and to the lack of a systematic database of co-infected patients in the city, which made it difficult to obtain results regarding the final outcome of TB treatment, patient survival or availability of antiretroviral drugs in the outpatient program. The date of death was not available either, so survival time could not be estimated. Bearing in mind that this study was conducted in a tertiarycare hospital, it would be necessary to conduct additional studies in centers with different levels of complexity to better characterize the co-infection in our population and, of course, to identify the main challenges for their diagnosis and treatment. Given that approximately half of the patients was previously diagnosed with HIV and, yet, they advanced to severe immunosuppression, studying this group and identifying missed opportunities for linkage to care and antiretroviral therapy initiation is a public health imperative.
In conclusion, our study shows that even after 35 years of HIV pandemic, TB is still a leading cause of advanced HIV diagnosis in our patients. The coinfections affected young adults not aware of risky sexual behaviors who had limited access to HIV testing and presented with both extrapulmonary and pulmonary TB. As their resistance to rifampicin and/or MDRTB is around three times higher than in the general population, and patients frequently have to stop TB drugs because of liver toxicity (about 10\%), which cannot be predicted by available biomarkers, it is always necessary to monitor liver function closely during TB therapy and rule out drug resistance.

\section{Acknowledgements}

To the medical students who participated in the data collection, Sebastián Osorio, Natalia Vélez and Jazmín Serna, and the data analyst Diego Bastidas, for his collaboration in the analysis. To Dr. Yoav Keynan for his critical review of the paper, the input and the English proofreading.

\section{Conflict of interests}

The authors declared no conflict of interests.

\section{Financing}

The present study received fianancial support from the Comité para el Desarrollo de la Investigación (CODI), Universidad de Antioquia.

\section{References}

1. World Health Organization Press. Global Tuberculosis Report 2016. Accessed: December 10, 2016. Available from: http://apps.who.int/iris/bitstream/10665/250441/1/97892 41565394-eng.pdf?ua=1

2. Yimer G, Gry M, Amogne W, Makonnen E, Habtewold A, Petros Z, et al. Evaluation of patterns of liver toxicity in patients on antireroviral and anti-tuberculosis drugs: A prospective four arm observational study in Ethiopian patients. PLoS One. 2014:9:e94271. https://doi.org/10.1371/ journal.pone.0094271

3. Rossato D, Manica A, Tarso P. Factors associated with delayed diagnosis of tuberculosis in hospitalized patients in a high TB and HIV burden setting: A cross-sectional. BMC Infect Dis. 2012;12:57. https://doi.org/10.1186/1471-2334$12-57$

4. Villegas L, Otero L, Sterling TR, Huaman MA, van der Stuyft P, Gotuzzo E, et al. Prevalence, risk factors, and treatment outcomes of isoniazid- and rifampicin-monoresistant pulmonary tuberculosis in Lima, Perú. PLoS One. 2016;11:e0152933. https://doi.org/10.1371/journal.pone. 0152933

5. World Health Organization. Definitions and reporting framework for tuberculosis - 2013 revision (updated December 2014). Geneva: WHO; 2013. p. 3. 
6. Saukkonen JJ, Cohn DL, Jasmer RM, Schenker S, Jereb JA, Nolan CM, et al. An official ATS statement: Hepatotoxicity of antituberculosis therapy. Am J Respir Crit Care Med. 2006;174:935-52. https://doi.org/10.1164/ rccm.200510-1666ST

7. Rueda ZV, López L, Vélez LA, Marín D, Giraldo MR, Pulido $\mathrm{H}$, et al. High incidence of tuberculosis, low sensitivity of current diagnostic scheme and prolonged culture positivity in four Colombian prisons. A cohort study. PLoS One. 2013;8:e80592. https://doi.org/10.1371/journal. pone.0080592

8. Hernández-Sarmiento JM, Dávila-Osorio VL, MartínezSánchez LM, Restrepo-Serna L, Grajales-Ospina DC, Toro-Montoya AE, et al. Tuberculosis in indigenous communities of Antioquia, Colombia: Epidemiology and beliefs. J Immigr Minor Health. 2013;15:10-6. https://doi. org/10.1007/s10903-012-9688-1

9. Machado JE, Martínez JW. Asociación tuberculosis y VIH en pacientes de Pereira, Colombia. Colombia Médica. 2005;36:239-43.

10. García I, Merchán A, Chaparro P, López L. Panorama de la coinfección tuberculosis/VIH en Bogotá, 2001. Biomédica. 2004;24(Supl.1):132-7. https://doi.org/10.7705/ biomedica.v24iSupp1.1312

11. Gavilanes J, Hernández I, Garzón J, Varela E, Bilbao O, Guerrero J, et al. Prevalencia de la coinfección VIH/TB en pacientes tuberculosos diagnosticados en el municipio de Pasto. Rev Univ Salud. 2010;12:50-6.

12. Arenas N, Ramírez N, González G, Rubertone S, García A, Gómez-Marín J, et al. Estado de la coinfección tuberculosis/virus de la inmunodeficiencia humana en el municipio de Armenia (Colombia): experiencia de 10 años. Infectio. 2012;16:140-7. https://doi.org/10.1016/S0123-9392 (12)70003-6

13. de Paz D, Potes L, Quiñónez E, Martínez LF, Cepeda M, Guarín N, et al. Resistencia a fármacos antituberculosis en pacientes coinfectados con tuberculosis y virus de la inmunodeficiencia humana, en un hospital de referencia de 2007 a 2010 en Cali (Colombia). Infectio. 2012;16:161-5. https://doi.org/10.1016/S0123-9392(12)70006-1

14. Pañuela-Epalza M, Vásquez-Beltrán M, De La RosaBarraza K, Hernández-Tapia H, Collazos-Daza J, YanesMiranda Y. Factores asociados a la coinfección VIH/SIDAtuberculosis Barranquilla (Colombia), 2003-2004. Revista Científica Salud Uninorte. 2006;22:5-19.

15. Cohen R, Muzaffar S, Capellan J, Azar H, Chinikamwala $\mathbf{M}$. The validity of classic symptoms and chest radiographic configuration in predicting pulmonary tuberculosis. Chest. 1996;109:420-3.

16. Padmapriyadarsini C, Tripathy S, Sekar L, Bhavani PK, Gaikwad N, Annadurai S, et al. Evaluation of a diagnostic algorithm for sputum smear-negative pulmonary tuberculosis in HIV-infected adults. J Acquir Immune Defic Syndr. 2013;63:331-8. https://doi.org/10.1097/QAI. Ob013e31829341af

17. Vélez L, Correa LT, Maya MA, Mejía P, Ortega J, Bedoya $\mathrm{V}$, et al. Diagnostic accuracy of bronchoalveolar lavage samples in immunosuppressed patients with suspected pneumonia: Analysis of a protocol. Respir Med. 2007;101: 2160-7. https://doi.org/10.1016/j.rmed.2007.05.017
18. Johnson JL, Vjecha MJ, Okwera A, Hatanga E, Byekwaso F, Wolski K, et al. Impact of human immunodeficiency virus type-1 infection on the initial bacteriologic and radiographic manifestations of pulmonary tuberculosis in Uganda. Makerere University-Case Western Reserve University Research Collaboration. Int J Tuberc Lung Dis. 1998;2:397-404.

19. Getahun H, Harrington M, O’Brien R, Nunn P. Diagnosis of smear-negative pulmonary tuberculosis in people with HIV infection or AIDS in resource-constrained settings: Informing urgent policy changes. Lancet. 2007;369:2042-9. https://doi.org/10.1016/S0140-6736(07)60284-0

20. Kivihya-Ndugga L, van Cleeff M, Juma E, Kimwomi J, Githui W, Oskam L, et al. Comparison of PCR with the routine procedure for diagnosis of tuberculosis in a population with high prevalences of tuberculosis and human immunodeficiency virus. J Clin Microbiol. 2004;42:1012-5. https://doi.org/10.1128/JCM.42.3.1012-1015.2004

21. Tamhane A, Chheng P, Dobbs T, Mak S, Sar B, Kimerling ME. Predictors of smear-negative pulmonary tuberculosis in HIV-infected patients, Battambang, Cambodia. Int J Tuberc Lung Dis. 2009;13:347-54.

22. da Silva RM, Machado T, Bazzo ML. Diagnosis of the pulmonary tuberculosis by polymerase chain reaction: $A$ comparative study between HIV-positive and -negative individuals. Braz J Microbiol. 2012;43:261-5.

23. Rojas MY, Polo CL. Informe de actividades realizadas por la Red Nacional de Laboratorios para la vigilancia de la resistencia de Mycobacterium tuberculosis a los fármacos antituberculosos en Colombia, 2013. Accessed: June 19, 2016. Available from: http://www.ins.gov.co/lineas-de-accion/ Red-Nacional-Laboratorios/Documentacin\%20Micobacterias/ INFORME\%20DE\%20LA\%20VIGILANCIA\%20DE\%20 LA\%20RESISTENCIA\%20DE\%20MYCOBACTERIUM\%20 TUBERCULOSIS\%20A\%20LOS\%20F\%C3\%81RMACOS\%20 ANTITUBERCULOSOS\%202013.pdf

24. Dheda K, Warren RM, Zumla A, Grobusch MP. Extensively drug-resistant tuberculosis: Epidemiology and management challenges. Infect Dis Clin North Am. 2010;24:705-25. https://doi.org/10.1016/j.idc.2010.05.001

25. World Health Organization. Anti-tuberculosis drug resistance in the world: Fourth Global report. Geneva: WHO; 2008. Accessed: June 19, 2016. Available from: http://www. who.int/tb/publications/2008/drs_report4_26feb08.pdf

26. Luetkemeyer A.Tuberculosis and HIV. HIV InSite Knowledge Base Chapter. Accessed: June 15, 2016. Available from: http://hivinsite.ucsf.edu/InSite?page=kb-05-01-06\#S3X

27. Li J, Munsiff SS, Driver CR, Sackoff J. Relapse and acquired rifampin resistance in HIV-infected patients with tuberculosis treated with rifampin- or rifabutin-based regimens in New York City, 1997-2000. Clin Infect Dis. 2005;41:83-91. https://doi.org/10.1086/430377

28. Ahmad S, Mokaddas E. Recent advances in the diagnosis and treatment of multidrug-resistant tuberculosis. Respir Med. 2009;103:1777-90. https://doi.org/10.1016/j.rmed. 2009.07.010

29. King L, Ahuja S. TB and HIV co-infection: Current trends, diagnosis and treatment update. The PRN Notebook. October 2006. Accessed: June 15, 2016. Available from: http://www.prn.org/images/pdfs/660_king_liza_v11n2-1.pdf 
30. Saha A, Shanthi FX, Winston AB, Das S, Kumar A, Michael JS, et al. Prevalence of hepatotoxicity from antituberculosis therapy: A five-year experience from South India. J Prim Care Community Health. 2016;7:171-4. https:// doi.org/10.1177/2150131916642431

31. Wejse C, Furtado A, Camara C, Luneborg-Nielsen M, Sodemann M, Gerstoft J, et al. Impact of tuberculosis treatment on CD4 cell count, HIV RNA, and p24 antigen in patients with HIV and tuberculosis. Int $\mathrm{J}$ Tuberc Lung Dis. 2013;17:e907-12. https://doi.org/10.1016/j.ijid.2013.05.003

32. Uthman OA, Okwundu C, Gbenga K, Volmink J, Dowdy D, Zumla A, et al. Optimal timing of antiretroviral therapy initiation for hiv-infected adults with newly diagnosed pulmonary tuberculosis: A systematic review and metaanalysis. Ann Intern Med. 2015;163:32-9. https://doi.org/10. 7326/M14-2979

33. Marcy O, Laureillard D, Madec Y, Chan S, Mayaud C, Borand $\mathrm{L}$, et al. Causes and determinants of mortality in HIV-infected adults with tuberculosis: An analysis from the CAMELIA ANRS 1295-CIPRA KH001 randomized trial. Clin Infect Dis. 2014;59:435-45. https://doi.org/10.1093/cid/ ciu283. 